\title{
PENGARUH SUPERVISI MANEJERIAL DAN MOTIVASI KERJA TERHADAP KINERJA KEPALA SEKOLAH PADA SEKOLAH DASAR NEGERI MENURUT PERSEPSI GURU SE-KOTA PADANG PANJANG
}

\section{Erichyat Putra}

Educational of Islamic Management Program, Post Graduate, Institute State of Islamic Batusangkar e-mail: erchyat_putra@yahoo.com

\begin{abstract}
Abstarct: The background of the research was the poor performance of the elementary school headmasters so that their main tasks and functions had not been fulfilled yet. It was researched based on elementary schools teachers'perceptions in Padang Panjang. The purpose of this research was to find out the influence of schools headmasters' managerial supervision and working motivations towards their performance. The results of the research found that: (1) the schools Headmasters' managerial supervisions had positive and significant influence towards their professionalism, namely $17.70 \%$; (2) their working motivations had positive and significant influence on their professionalism namely 14.40\%; and (3) their managerial supervision (X1) and working motivation (X2) had positive and significant influences towards the Headmasters performances, namely $39.50 \%$.
\end{abstract}

Keywords: Managerial supervision, working motivations and the headmasters' performance.

\section{PENDAHULUAN}

Kepala sekolah dapat didefinisikan sebagai seorang tenaga fungsional guru yang diberi tugas untuk memimpin suatu sekolah dimana terjadi interaksi antara guru yang memberi pelajaran dan murid yang menerima pelajaran (Wahjosumidjo, 2002: 83). Kepala sekolah merupakan salah satu komponen pendidikan yang paling penting berperan dalam meningkatkan kualitas pendidikan (Mulyasa, Enco, 2009 :24). Kepala sekolah adalah pemimpin pendidikan tingkat satuan pendidikan yang harus memiliki dasar kepemimpinan yang kuat (Mulyasa, HE, 2011: 16). Kepala sekolah merupakan salah satu komponen yang berpengaruh terhadap terciptanya proses dan hasil pendidikan yang berkualitas.

Oleh karena itu upaya perbaikan apapun yang dilakukan untuk meningkatkan kualitas pendidikan tidak akan memberikan sumbangan yang signifikan tanpa didukung oleh kepala sekolah yang profesional dan berkualitas. Supervisi adalah suatu aktivitas pembinaan yang direncanakan untuk membantu para guru dan pegawai sekolah lainnya dalam melakukan pekerjaan mereka 
secara efektif(M. Ngalim Purwanto, 2005: 76). Fungsi supervisi dalam pendidikan bukan hanya sekedar kontrol melihat apakah segala kegiatan telah dilaksanakan sesuai dengan rencana atau program yang telah digariskan, tetapi lebih dari itu, supervisi dalam pendidikan mengandung pengertian yang luas. Kegiatan supervisi mencakup penentuan kondisi-kondisi atau syarat-syarat personil maupu material yang diperlukan untuk terciptanya situasi belajar mengajar yang efektif.

Motivasi kerja seorang kepala sekolah bisa terwujud apabila dalam melaksanakan tugas kerjanya ada dorongan yang kuat dari dalam dirinya agar mampu mewujudkan suasana lingkungan sekolah yang menyenangkan dan membuat semua warga sekolah merasa nyaman, serta didukung oleh guru yang mempunyai integritas.

Dalam Islam, motivasi kerja itu tidak hanya sebatas duniawi saja tapi berlanjut kepada akhirat. Dalam bekerja seorang harus bekerja dengan baik dan benar semata-mata mengharap ridha Allah SWT. Bekerja dengan cara terbaik sebagai wujud tanggung jawab terhadap kerja dan tugas yang diamanahkan, Menjauhi segala bentuk kemungkaran untuk dirinya dan orang lain dalam bekerja. Misalnya, tidak malasmalasan, merugikan rekan kerja, Taat pada aturan, Hanya menginginkan hasil pekerjaan yang baik dan halal. Hal ini sesuai dengan firman Allah SWT yang menjamin balasan kepada orang-orang yang bertaqwa dalam kehidupan ini, termasuk dalam bekerja. Firman Allah SWT (Depag RI, 1989: 945.):

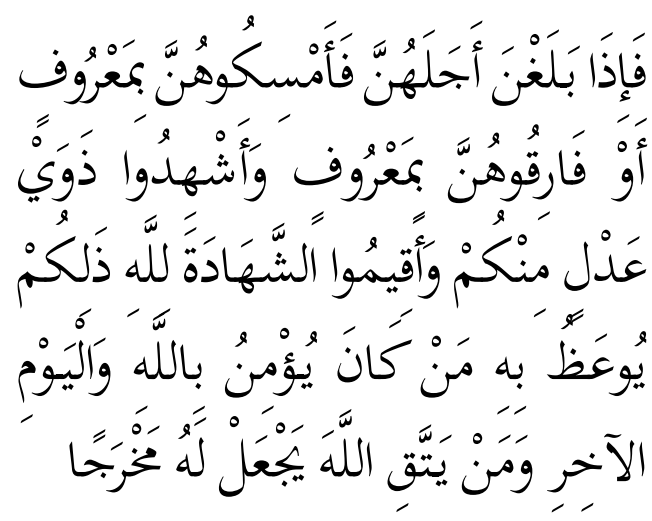

Apabila mereka telah mendekati akhir iddahnya, Maka rujukilah mereka dengan baik atau lepaskanlah mereka dengan baik dan persaksikanlah dengan dua orang saksi yang adil di antara kamu dan hendaklah kamu tegakkan kesaksian itu karena Allah. Demikianlah diberi pengajaran dengan itu orang yang beriman kepada Allah dan hari akhirat. barangsiapa bertakwa kepada Allah niscaya dia akan mengadakan baginya jalan keluar ( QS.Aththolaaq:2).

Kepala sekolah merupakan salah satu faktor penentu keberhasilan setiap upaya pendidikan. Kinerja kepala sekolah dalam merencanakan dan melaksanakan pembelajaran, merupakan faktor utama dalam pencapaian keberhasilan di sekolah. Secara sempit dapat diinterprestasikan sebagai pembimbing atau fasilitator bagi sekolah, selain bertanggung jawab meningkatkan mutu pendidikan. Kepala sekolah mempunyai tugas dan tanggungjawab yang berat, maka idealnya kepala sekolah harus memiliki kualifikasi 
akademik yang memadai, pengalaman kerja dan motivasi kerja yang positif.

Untuk dapat menilai Kinerja kepala sekolah, harus dilihat dari bagaimana seorang kepala sekolah melaksanakan tugas fokok dan fungsi kepala sekolah itu sendiri. Yaitu membahas kinerja kepala sekolah dengan indikator educator, manajer, administrator, supervisor, leader, innovator dan motivator (EMASLIM).

Dalam paradigma baru manajemen pendidikan (E, Mulyasa, r..4:१v), kepala sekolah setidaknya harus mampu berfungsi sebagai educator, manajer, administrator, supervisor, leader, innovator dan motivator (EMASLIM).

Adapun penjabaran dari tugas dan fungsi kepala sekolah (E, Mulyasa, 2009: 97) adalah:

a. Kepala Sekolah sebagai Educator (pendidik)

b. Kepala Sekolah sebagai Manajer

c. Kepala Sekolah sebagai Administrator

d. Kepala Sekolah sebagai Supervisor

e. Kepala Sekolah sebagai Leader

f. Kepala Sekolah sebagai Innovator

g. Kepala Sekolah sebagai Motivator.

Beberapa Sekolah Dasar di Kota Padang Panjang menunjukkan bahwa terdapat banyak kesenjangan untuk menilai kinerja kepala sekolah, di antaranya adalah (1) Kepala sekolah tidak mampu mengelola sekolah dengan baik; (2) Kepala sekolah tidak mampu melakukan terobosan secara kreatif dan inovatif dalam bidang kepemimpinan pembelajaran; (3) Kepala sekolah tidak dapat menciptakan rasa aman di lingkungan sekolah; dan (4) Kepala sekolah tidak mampu menciptakan budaya dari iklim sekolah yang kondusif dan inovatif bagi pembelajaran serta tidak memegang teguh tujuan sekolah.

Penelitian ini bertujuan untuk mengetahui seberapa besar Pengaruh Supervisi Manajerial dan motivasi kerja terhadap Kinerja Kepala Sekolah pada Sekolah Dasar Negeri menurut persepsi guru se Kota Padangpanjang?

\section{KAJIAN PUSTAKA}

Supervisi adalah kegiatan yang dilakukan oleh pengawas satuan pendidikan dalam rangka membantu kepala sekolah, guru dan tenaga kependidikan lainnya guna meningkatkan mutu dan efektivitas penyelenggaraan pendidikan dan pembelajaran. Supervisi ditujukan pada dua aspek yakni: manajerial dan akademik. Supervisi manajerial menitikberatkan pada pengamatan pada aspek-aspek pengelolaan dan administrasi sekolah yang berfungsi sebagai pendukung (supporting) terlaksananya pembelajaran. Sementara supervisi akademik menitik beratkan pada pengamatan supervisor terhadap kegiatan akademik, berupa pembelajaran baik di dalam maupun di luar kelas (Akhmad Sudrajat, 2009: 47). 
Dalam Panduan Pelaksanaan Tugas Pengawas Sekolah/Madrasah dinyatakan bahwa supervisi manajerial adalah supervisi yang berkenaan dengan aspek pengelolaan sekolah yang terkait langsung dengan peningkatan efisiensi dan efektivitas sekolah yang mencakup perencanaan, koordinasi, pelaksanaan, penilaian, pengembangan kompetensi sumber daya manusia (SDM) kependidikan dan sumberdaya lainnya (Akhmad Sudrajat, 2009: 27).

Motivasi kerja merupakan salah satu faktor yang turut menentukan kinerja seseorang. Besar atau kecilnya pengaruh motivasi pada kinerja seseorang tergantung pada seberapa banyak intensitas motivasi yang diberikan. Berdasarkan definisi tersebut, dapat dirumuskan konstruk motivasi adalah "suatu proses yang dilakukan untuk menggerakkan kepala sekolah agar perilaku mereka dapat diarahkan pada upaya-upaya yang nyata untuk mencapai tujuan pendidikan yang telah ditetapkan (Uno, H. Hamzah B, 2011: 71-72).

Manfaat dari motivasi kerja yang utama adalah menciptakan gairah kerja, sehingga produktivitas kerja meningkat. Sementara itu, manfaat yang diperoleh karena bekerja dengan orang-orang yang termotivasi, maka pekerjaan dapat diselesaikan dengan tepat. Artinya pekerjaan diselesaikan sesuai dengan standar dan dalam skala waktu yang sudah ditentukan, serta orang senang melakukan pekerjaannnya. Sesuatu yang dikerjakan karena terdorong oleh motivasi akan membuat orang senang mengerjakannya.

Istilah kinerja berasal dari kata Job Performance atau Actual Performance (prestasi kerja atau prestasi sesungguhnya yang dicapai oleh seseorang). Pengertian kinerja (prestasi kerja) adalah "hasil kerja secara kualitas dan kuantitas yang dicapai oleh seseorang dalam melaksanakan tugasnya dengan tanggung jawab yang diberikan kepadanya (Mangkunegara, A.A. Anwar Prabu, 2004: 67)

Untuk dapat menilai Kinerja kepala sekolah, harus dilihat dari bagaimana seorang kepala sekolah melaksanakan tugas fokok dan fungsi kepala sekolah itu sendiri. Penelitian ini membahas kinerja kepala sekolah dengan indikator EMASLIM. Dalam paradigma baru manajemen pendidikan (E, Mulyasa, 2009:97-98), kepala sekolah setidaknya harus mampu berfungsi sebagai educator, manajer, administrator, supervisor, leader, innovator dan motivator (EMASLIM).

Penelitian ini dilakukan mulai dari bulan Oktober 2016 sampai bulan Februari 2017, dengan populasi seluruh seluruh guru Sekolah Dasar Negeri yang ada di Kota Padang Panjang yang berjumlah 355 orang. Sampel diambil dengan menggunakan teknik menurut (Wiliam G. Cochran,1977:91) stratified proportional random sampling, dengan jumlah sampel sebanyak 75 orang guru.

\section{HASIL PENELITIAN DAN PEMBAHASAN}

Tingkat pencapaian skor kinerja Kepala Sekolah termasuk cukup (78,36\%). Hasil 
ini menunjukkan bahwa kinerja Kepala Sekolah tersebut termasuk kategori cukup baik. Secara rinci dapat dijelaskan bahwa indikator pertama Kinerja Kepala Sekolah adalah Kepala Sekolah sebagai Edukator, dengan tingkat pencapaian $77,73 \%$ atau Cukup, indikator kedua Kepala Sekolah sebagai Manejer, dengan tingkat pencapaian $81,47 \%$ atau Baik, indikator ketiga Kepala Sekolah sebagai Administrator, dengan tingkat pencapaian 78,56\% atau cukup, indikator keempat Kepala Sekolah sebagai Supervisor, dengan tingkat pencapaian $74,27 \%$ atau Cukup, indikator kelima adalah Kepala Sekolah sebagai Leader, dengan tingkat pencapaian $75,53 \%$ atau Cukup, indikator keenam adalah Kepala Sekolah sebagai Inovator, dengan tingkat pencapaian $80,62 \%$ atau baik, indikator ketujuh adalah Kepala Sekolah sebagai Motivator, dengan tingkat pencapaian $78,13 \%$ atau cukup.

Secara rinci dapat dijelaskan bahwa indikator pertama Motivasi Kerja adalah Motivasi Internal, dengan tingkat pencapaian 79,26\% atau Cukup, indikator kedua Motivasi Eksternal, degan tingkat pencapaian $80,83 \%$ atau baik.

Hasil analisis data dan pengujian hipotesis menunjukkan bahwa ketiga hipotesis telah teruji secara empiris. Dari hasil analisi data menunjukkan bahwa Supervisi Manajerial dan Motivasi Kerja baik secara sendiri-sendiri maupun secara bersama-sama memiliki pengaruh yang berarti dengan Kinerja Kepala Sekolah. Adapun besarnya pengaruh Supervisi Manajerial terhadap Kinerja Kepala Sekolah adalah 17,70\%, pengaruh Motivasi Kerja terhadap Kinerja Kepala Sekolah adalah 14,40\%, dan apabila secara bersama-sama Supervisi Manajerial dan Motivasi Kerja terhadap Kinerja Kepala Sekolah secara secara bersama - sama memiliki pengaruh yang berarti yakni sebesar 39,5\%.

Sebagaimana dijelaskan dalam teori Kinerja Kepala Sekolah, bahwa Kinerja kepala sekolah adalah kemampuan untuk melaksanakan pekerjaan atau tugas dan fungsi yang dimiliki kepala sekolah dalam menyelesaikan suatu pekerjaan di sekolah yang dipimpin. Dilihat dari ukuran keberhasilan sekolah, kinerja kepala sekolah dapat ditampilkan dalam keberhasilan yang berkenaan dengan pengelolaan sekolah, kegiatan pembelajaran, ketenagaan, sarana prasarana, keuangan, lingkungan sekolah, dan hubungan sekolah dengan masyarakat (Suhardi. 2012: 96). Melihat data-data penelitian tentang kinerja Kepala Sekolah, tergambar bahwa Kinerja Kepala Sekolah pada Sekolah Dasar Negeri di Kota Padangpanjang berada pada kategori cukup, dengan demikian kinerja Kepala Sekolah perlu ditingkatkan lagi agar bisa mencapai kearah yang baik.

Motivasi merupakan suatu bagian yang sangat penting dalam suatu lembaga. Para tenaga kependidikan akan bekerja dengan sungguh-sungguh apabila memiliki motivasi 
yang tinggi. Jika para tenaga kependidikan memiliki motivasi yang positif maka ia akan memperlihatkan minat, mempunyai perhatian, dan ingin ikut serta dalam suatu tugas atau kegiatan. Dengan kata lain, "seseorang tenaga pendidikan akan melakukan semua pekerjaannya dengan baik apabila ada faktor pendorongnya (motivasi).

Motivasi kerja yang diberikan oleh lembaga pendidikan akan mendorong seorang kepala sekolah untuk melakukan promosi jabatan ke arah yang lebih baik. Selain itu, juga akan mendorong kepala sekolah untuk memberikan semua kemampuan yang dimilikinya secara maksimal dan bukan hanya kemampuan umum mendasar dari setiap pribadinya, seperti halnya kemampuan intelektual dan fisik belaka. Kemampuan kepala sekolah tersebut merupakan wujud dari kemauan para kepala sekolah sendiri untuk dilatih dan dikembangkan keahlian dan pengetahuannya dalam menerima tugas dan tanggung jawab pekerjaan yang lebih besar. Termasuk di dalamnya juga adalah sikap, hasrat dan keinginan serta kesiapan mental untuk mau menyesuaikan diri dan dilatih menghadapi tuntutan tugas dan tanggung jawab pekerjaan yang baru. Tentunya "kemampuan kepala sekolah tersebut tidak lepas dari sejumlah potensi atau keunggulan pribadi yang ada dan dimiliki seorang kepala sekolah saat itu, seperti usia, jenis kelamin, tingkat intelegensia, tingkat pendidikan, latar belakang keterampilan dan keahlian yang dikuasai, pengetahuan dan pengalaman kerja mereka.

Motivasi kerja merupakan proses psikologis seseorang untuk beraktivitas yang dipengaruhi oleh faktor dari dalam maupun dari luar dirinya. Motivasi dari dalam (instrinsik) merupakan dorongan yang berasal dari dalam diri seseorang, misalnya: kepala sekolah bekerja karena memahami tujuan, jenis, teknis dan metode kerja secara tepat dan jelas sehingga akan merasa puas bila pekerjaan itu dapat diselesaikan dengan tepat dan benar. Motivasi dari luar (ekstrinsik) merupakan "dorongan yang diperoleh dari luar diri seseorang, misalnya: kepala sekolah terdorong untuk bekerja karena mendapat upah atau gaji yang memadai, mendapat pujian dari orang, dan mendapat jabatan atau promosi.

Motivasi internal kepala sekolah dan motivasi eksternal kepala sekolah, akan membuat seluruh komponen yang menyangkut dengan Kinerja Kepala Sekolah dapat dipenuhi dengan baik. Dengan demikian dapat dikatakan bahwa Kinerja Kepala Sekolah akan dapat terpenuhi bila Motivasi Kerja kepala sekolah berjalan dengan baik dan semestinya.

Dalam hal ini peran yang dijalankan motivasi kerja adalah sebagai berikut: Pemberi dorongan kepada ke kepala sekolah untuk melaksanakan pekerjaan nya dengan baik. Dalam analisis data tergambar bahwa tingkat pencapaian responden terhadap variabel Motivasi Kerja adalah 79,90\% atau cukup. 
Sesuai dengan hipotesis yang di nyatakan "Motivasi Kerja berpengaruh positif dan signifikan terhadap Kinerja Kepala Sekolah" dapat diterima dan telah teruji pada tarap kepercayaan 95\%. Selanjutnya dapat diinterprentasikan bahwa Motivasi Kerja memiliki Pengaruh positif dan signifikan terhadap Kinerja Kepala Sekolah sebesar $14,40 \%$. Hal ini menunjukkan bahwa 14,40\% keberhasilan Kinerja Kepala Sekolah ditentukan oleh Motivasi Kerja

Secara operasional Kompetensi Supervisi Manajerial dalam penelitian ini didefenisikan adalah kegiatan yang dilakukan oleh pengawas/Kepala Sekolah dalam rangka membantu kepala guru dan tenaga kependidikan lainnya guna meningkatkan mutu dan efektivitas penyelenggaraan pendidikan dan pembelajaran. Menurut hasil penelitian yang penulis lakukan kondisi aktual Supervisi Manajerial ternyata secara umum kondisinya tergolong baik $(80,43 \%)$. Dengan demikian, secara umum Supervisi Manajerial baik dalam (1) Membuat perencanaa untuk berbagai tingkatan perencanaan, (2) Pelaksanaan Supervisi Manajerial, (3) Koordinasi sesuai dengan prinsip pengelolaan yang akuntabel, transparan, dan efisien dan (4) Penilaian pelaksanaan program kegiatan Supervisi Manajerial dengan prosedur yang tepat, serta merencanakan tindak lanjutnya dan baik dalam mengembangkan SDM warga sekolah yang kepala sekolah pimpin.
Setelah dilakukan pengkajian mendalam melalui proses analisis di atas, maka diyakini bahwa hipotesis penelitian yang menyatakan "Supervisi Manajerial berpengaruh terhadap Kinerja Kepala Sekolah" dapat diterima dan telah teruji pada tarap kepercayaan 95\%. Selanjutnya dapat diinterprentasikan bahwa Supervisi Manajerial memiliki Pengaruh positif dan signifikan terhadap Kinerja Kepala Sekolah sebesar 17,70\%. Hal ini menunjukkan bahwa 17,70\% keberhasilan Kinerja Kepala Sekolah ditentukan oleh Supervisi Manajerial.

Kepala sekolah dalam melakasanakan kerja untuk mencapai kinerja yang baik seperti kepala sekolah sebagai edukator, kepala sekolah sebagai manajer, kepala sekolah sebagai administrator, kepala sekolah sebagai supervisor, kepala sekolah sebagai Leader, kepala sekolah sebagai inovator dan kepala sekolah sebagai motivator dipengaruhi oleh supervisi manajerialnya.

Melihat data-data penelitian tentang kinerja kepala sekolah, tergambar bahwa kinerja kepala sekolah cukup baik, dengan demikian kinerja kepala sekolah perlu ditingkatkan lagi agar bisa mencapai kearah yang baik, kinerja kepala sekolah bagaimana kepala sekolah sebagai edukator, kepala sekolah sebagai manajer, kepala sekolah sebagai administrator, kepala sekolah sebagai supervisor, kepala sekolah sebagai Leader, kepala sekolah sebagai inovator dan kepala sekolah sebagai motivator yang musti di 
tingkatkan dengan meningkatatkan supervisi manajerial oleh kepala sekolah tersebut

Pengaruh Supervisi Manajerial dan Motivasi Kerja secara bersama sama terhadap Kinerja Kepala Sekolah. Supervisi Manajerial merupakan salah satu kunci keberhasilan pelaksanaan program pembelajaran pada suatu Sekolah. Supervisi Manajerial diperkirakan berpengaruh terhadap Kinerja Kepala Sekolah yang ada pada satuan pendidikan. Perencanaan, pelaksanaan, Koordinasi, pengembangan SDM dan Penilaian akan mempengaruhi kepala sekolah dalam melakasanakan tugas pokok dan fungisnya, baik kepala sekolah sebagai edukator, manajer, administrator, atau yang lebih sering di kenal dengan EMASLIM. Pelakasanaan tugas fokok dan fungsinya secara baik akan muncul apabila Motivasi Kerja yang datang dari dalalm diri maupun dorongan yang datang dari luar diri kepala sekolah berjalan dengan baik. Motivasi kerja yang baik akan mendukung setiap aktivitas kepala sekolah sehingga memperlancar proses pelakasanaan kinerja kepala sekolah

Supervisi Manajerial dan Motivasi Kerja secara bersama-sama diperkirakan berpengaruh terhadap kinerja kepala sekolah pada SDN yang ada di Kota Padangpanjang. Untuk mengetahui bagaimana Pengaruh Supervisi Manajerial dan Motivasi Kerja secara bersama-sama terhadap Kinerja Kepala Sekolah, maka ditawarkan hipotesis "Supervisi Manajerial dan Motivasi Kerja secara bersama-sama berpengaruh positif dan signifikan terhadap kinerja kepala sekolah". dapat diterima dan telah teruji pada tarap kepercayaan 95\%. Selanjutnya dapat diinterprentasikan bahwa Supervisi Manajerial dan Motivasi Kerja memiliki Pengaruh yang positif dan signifikan terhadap kinerja kepala sekolah sebesar 39,5\%. Hal ini menunjukkan bahwa 39,5\% kinerja kepala sekolah ditentukan oleh Supervisi Manajerial dan Motivasi Kerja . Dengan kata lain secara simultan kedua faktor tersebut mempunyai Pengaruh dengan kinerja kepala sekolah.

Dengan menggunakan analisis korelasi dan regresi berganda antara variabel bebas Supervisi Manajerial $\left(\mathrm{X}_{1}\right)$ dan Motivasi Kerja $\left(X_{2}\right)$ dengan variabel terikat Kinerja Kepala Sekolah (Y) dapat diketahui besarnya koefisien korelasi Ry.1.2 $=0.629$ dan koefisien determinasi sebesar $\mathrm{R}^{2}$ y.1.2 = 0.395. Dapat disimpulkan bahwa 39,5\% variasi yang terjadi pada variabel Kinerja Kepala Sekolah disebabkan oleh kedua variabel bebas Supervisi Manajerial dan Motivasi Kerja, sementara sisanya 60,5\% disebabkan oleh faktor lain di luar variabel yang diteliti.

Setelah dilakukan pengujian secara statistik ternyata persamaan regresi yang diperoleh merupakan model yang baik untuk memperkirakan tingkat Kinerja Kepala Sekolah. Dengan demikian terdapat Pengaruh yang positif dan linear masingmasing variabel yang digunakan dalam penelitian. 
Untuk memperjelas gambaran Pengaruh Supervisi Manajerial dan Motivasi kerja terhadap kinerja kepala sekolah pada SDN kota Padangpanjang, maka di bawah ini dapat dilihat pada tabel berikut:

Tabel 31. Rangkuman Pengaruh antar Variabel

\begin{tabular}{|c|c|c|c|c|c|}
\hline NO & Variabel & Indikator & $\begin{array}{l}\text { \% Tingkat } \\
\text { Pencapaian }\end{array}$ & $\begin{array}{l}\text { \% Pengaruh } \\
\text { kpd Kinerja } \\
\text { kepala } \\
\text { sekolah }\end{array}$ & Ket \\
\hline \multirow{5}{*}{1} & \multirow{5}{*}{$\begin{array}{l}\text { Supervisi } \\
\text { Manajerial }\end{array}$} & a. Perencanaan & 77,47 & 16,62 & Cukup \\
\hline & & b. Pelaksanaan & 82,67 & 20,72 & Baik \\
\hline & & c. Koordinasi & 81,60 & 19,76 & Baik \\
\hline & & d. Penilaian & 89,71 & 23,43 & Baik \\
\hline & & $\begin{array}{l}\text { e. Pengembangan } \\
\text { SDM }\end{array}$ & 79,23 & 17,52 & Cukup \\
\hline \multirow{2}{*}{2} & \multirow{2}{*}{$\begin{array}{l}\text { Motivasi } \\
\text { Kerja }\end{array}$} & $\begin{array}{l}\text { a. Motivasi } \\
\text { Internal } \\
\end{array}$ & 79,26 & 16,58 & cukup \\
\hline & & $\begin{array}{l}\text { b. Motivasi } \\
\text { Eksternal } \\
\end{array}$ & 80,83 & 17,23 & Baik \\
\hline
\end{tabular}

Tabel di atas menggambarkan bahwa pengaruh Supervisi Manajerial terhadap kinerja kepala sekolah, masih ada indikator yang berada pada kategori cukup yakni perencanaan supervisi dan pengembangan SDM, sementara tiga indikator lainnya seperti Pelaksanaan, penilaian, Koordinasi berada kategori baik dan berpengaruh terhadap kinerja kepala sekolah.

Pengaruh variabel motivasi kerja terhadap kinerja kepala sekolah salah satu indikatornya masih berada pada kategori cukup yakni, Motivasi Internal (79,26\%), dan indikator Motivasi Eksternal yang memiliki kategori baik pengaruhnya terhadap Kinerja Kepala Sekolah yakni $(80,83 \%)$.

\section{PENUTUP}

\section{Kesimpulan}

Berdasarkan hasil penelitian dan analisis tentang kinerja kepala sekolah yang diperoleh dari data penelitian berkaitan dengan pengaruh Supervisi Manajerial dan Motivasi Kerja disimpulkan bahwa:

1. Supervisi Manajerial berpengaruh positif dan signifikan terhadap kinerja kepala sekolah sebesar $17,70 \%$. Ini berarti bahwa Supervisi Manajerial yang baik memberikan dampak kepada Kinerja Kepala Sekolah.

2. Motivasi Kerja berpengaruh positif dan signifikan terhadap kinerja kepala sekolah sebesar 14,40\%. Ini berarti bahwa Motivasi Kerja yang baik memberikan dampak kepada Kinerja Kepala Sekolah.

3. Supervisi Manajerial dan Motivasi Kerja secara bersama-sama (simultan) berpengaruh positif dan signifikan terhadap kinerja kepala sekolah sebesar 39,50\%. Hal ini menjelaskan bahwa untuk meningkatkan Kinerja Kepala Sekolah dapat dilakukan melalui peningkatan Motivasi Kerja bersamaan dengan perbaikan Supervisi Manajerial.

\section{Saran}

Berdasarkan hasil penelitian dan implikasi yang dikemukakan sebelumnya dapat disarankan beberapa hal sebagai berikut: 
1. Kepala sekolah SDN yang ada di Kota Padang Panjang dalam melaksankaan supervisi Manajerial agar dapat membuat Perencanaan yang baik dan lebih fokus untuk membina para guru, sehingga dengan perencanaan yang baik, supervisi manajerial kepala sekolah akan bisa dilaksanakan lebih baik. Kepala Sekolah juga dalam melaksanakan tupoksinya sebagai EMASLIM harus meningkatkan kinerjanya di bidang pengembangan SDM, apabila SDM di sutau sekolah dapat dikembangkan dengan baik oleh kepala sekolah, maka kinerja kepala sekolah akan nampak dan nyata dalam melaksanakan tupoksinya dengan baik, dengan demikian Kinerja Kepala Sekolah dapat meningkat.

2. Motivasi Kerja yang masih berkategori cukup baik hendaknya dapat ditingkatkan menjadi baik karena indikator Motivasi Internal (79,26\%) masih berada pada kategori cukup. Oleh sebab itu Motivasi Internal kepala sekolah harus ditingkatkan sebab jika motivasi internal kepala sekolah ini baik maka dorongan untuk bekerja kepela sekolah akan jauh lebih baik, dengan begitu Kinerja Kepala Sekolah akan semakin lebih baik.

3. Kepala Dinas Pendidikan Kota Padang Panjang disarankan untuk menyusun program pelatihan tentang tupoksi kepala sekolah dalam rangka meningkatkan kompetensi Supervisi Manajerial Kepala
Sekolah serta mengoptimalkan Motivasi Kerja, sehingga Kinerja Kepala Sekolah dapat ditingkatkan.

4. Bagi peneliti lain disarankan untuk melakukan studi mengenai Kinerja Kepala Sekolah dengan memperluas kajian tentang faktor-faktor lain yang dapat mempengaruhi Kinerja Kepala Sekolah.

\section{KEPUSTAKAAN ACUAN}

Cochran, Wiliam G. 1977, Sampling Techniques. Third Edition. New York: John Willey \& Sons.

Depag Republik Indonesia, 1989, Al-qur'an dan Terjemahannya, Semarang: CV. Alwaah

Mangkunegara, A.A. Anwar Prabu. 2004. Manajemen Sumber Daya Manusia Perusahaan. Bandung: Remaja Rosdakarya

Mulyasa, E. 2009. Menjadi Kepala Sekolah Profesional dalam Konteks Menyukseskan $M B S$ dan KBK. Bandung: Remaja Rodaskarya 2007, Menjadi Kepala Sekolah Profesional. Bandung: Remaja Rosdakarya. --------. 2002. Menjadi Kepala Sekolah Profesional. Bandung: Rosdakarya ......... 2011. Manajemen dan Kepemimpinan Kepala Sekolah. Jakarta: Bumi Aksara 
-------. 2011. Manajemen Berbasis Sekolah. Bandung: Remaja Rosdakarya

-.--_---, 2000, Manajemen Berbasis Sekolah, Bandung: PT. Remaja Rosda Karya

Ngalim Purwanto, M, 2005, Adminstrasi dan Supervisi Pendidikan, Bandung: PT Remaja Rosdakarya,

-------, 2006, Administrasi \& Supervisi Pendidikan. Bandung: Remaja Rosdakarya.
Sudrajat, Akhmad. Dimensi Kompetensi Supervisi Manajerial. Jakarta: Musyawarah kerja pengawas, 2009), http//depdiknas, diakses tanggal 23 Otober 2016

Uno, H. Hamzah B. 2011. Teori Motivasi dan Pengukurannya: Analisis di Bidang Pendidikan. Jakarta: Bumi Aksara

Wahjosumidjo. 2002. Kepemimpinan Kepala Sekolah. Jakarta: Raja Grafindo Persada 